\begin{tabular}{|c|c|}
\hline$=$ & $\begin{array}{c}\text { Media Kajian Pancasila dan Kewarganegaraan } \\
\text { http://ejournal.unima.ac.id/index.php/jce } \\
2599-1833 \text { (print) } \\
2621-3467 \text { (online) }\end{array}$ \\
\hline
\end{tabular}

\title{
Pengembangan buku revitalisasi dan reaktualisasi pancasila dalam kehidupan berbangsa dan bernegara menghadapi tantangan globalisasi
}

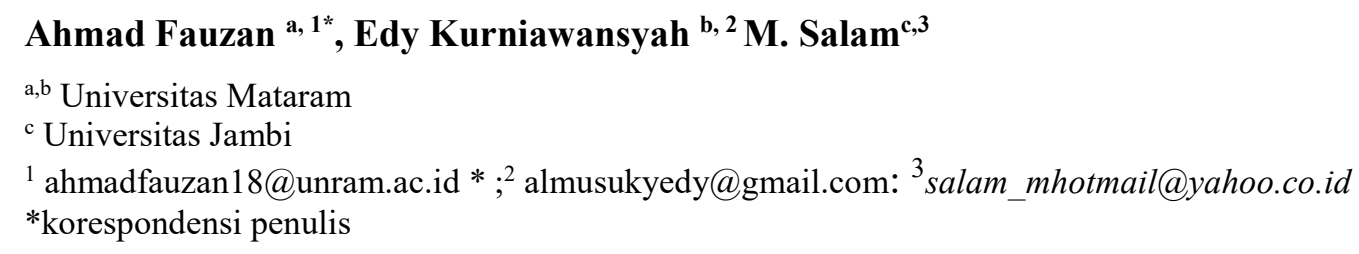

\begin{tabular}{ll}
\hline Informasi artikel & AB \\
\hline Sejarah artikel: & \\
Diterima: & \\
10 Desember 2020 & \\
Disetujui: & 16 Desember 2020
\end{tabular}

Kata kunci:

Revitalisasi

Reakatualisasi

Pancasila

\begin{abstract}
ABSTRAK
Penelitian ini bertujuan untuk mengembangkan Buku Revitalisasi dan Reaktualisasi Pancasila dalam cetak dan digital. Model penelitian ini adalah model pengembangan ADDIE. Model pengembangan ini dipilih karena peneliti akan mengembangkan produk dalam bentuk perangkat pembelajaran sehingga tahapannya cocok dengan menggunakan model ADDIE. Tahapan ADDIE terdiri atas analisis, desain, pengembangan, implementasi dan evaluasi. Hasil penelitian ini adalah pengembangan buku revitalisasi dan raeaktualisasi Pancasila dalam menghadapi tantangan globalisasi sanagat di perlukan bagi masyarakat intelektual maupun sosial untuk menjaga eksistensi nilai pancasila. Pada dasarnya globalisasi memang tidak bisa dihindari, tetapi bangsa Indonesia harus berbuat, harus menetapkan tekad untuk membangun kemandirian dan peningkatan kualitas moral dengan semangat modernisasi di era global dan tetap berpegang teguh kepada ideologi Pancasila serta cita-cita Proklamasi 17 Agustus 1945.
\end{abstract}

Keywords:

Revitalization and

Reactualization

Pancasila

\begin{abstract}
The development of books on the revitalization and re-actualization of Pancasila in the life of the nation and state faces the challenges of globalization. This research aims to develop the book Revitalization and Reactualization of Pancasila in print and digital. This research model is the ADDIE development model. This development model was chosen because researchers will develop products in the form of learning devices so that the stages are suitable for using the ADDIE model. The ADDIE stage consists of analysis, design, development, implementation and evaluation. The result of this research is the development of a book on revitalization and re-actualization of Pancasila in facing the challenges of globalization, which is necessary for both intellectual and social communities to maintain the existence of Pancasila values. Basically globalization is inevitable, but the Indonesian nation must act, must determine the determination to build independence and improve moral quality with the spirit of modernization in the global era and stick to the ideology of Pancasila and the ideals of the August 171945 Proclamation.
\end{abstract}

Copyright (C) 2019 (Ahmad Fauzan, dkk). All Right Reserved

\section{Pendahuluan}

Pancasila merupakan sumber dari segal sumber hukum di Negara Indonesia. Karya terbaik yang dimiliki oleh founding father bangsa yang tergali dari jati diri dan nilai-nilai luhur bangsa yang tidak dimiliki oleh bangsa lain. Hal tersebut memiliki keterkaitan antara sila-sila 
Pancasila yang tidak dapat terpisahkan karena saling menjiwai satu sama lainnya dengan demikian dengan sendirinya menjadi ciri khas dari semua kegiatan serta aktivitas desah nafas dan jatuh bangunnya perjalanan sejarah bangsa yang telah melewati masa-masa sulit dari jaman penjajahan sampai pada saat mengisi kemerdekaan (Azharul Faizin, 2020).

Penetapan Pancasila sebagai dasar negara memberikan pengertian bahwa negara Republik Indonesia adalah negara Pancasila. Hal itu mengandung arti bahwa negara harus tunduk kepadanya, serta membela dan melaksanakannya dalam seluruh perundang-undangan. Negara Pancasila adalah suatu negara yang didirikan, dipertahankan, dan dikembangkan dengan tujuan untuk melindungi dan mengembangkan martabat dan hak-hak azasi semua warga bangsa Indonesia (kemanusiaan yang adil dan beradab), agar masing-masing dapat hidup layak sebagai manusia, mengembangkan dirinya dan mewujudkan kesejahteraannya lahir batin selengkap mungkin, memajukan kesejahteraan umum, yaitu kesejahteraan lahir batin bagi seluruh rakyat, dan mencerdaskan kehidupan bangsa keadilan social. (Mutiani, 2016).

Saat ini banyak warga Negara Indonesia yang sudah asing mendengar Pancasila, kenapa demikian? Terdapat pergeseran nilai-nilai/ pertentangan nilain pancasila sehingga terjadi pasang surut masalah-masalah yang sedang dihadapi oleh negeri ini dikarenakan kurang optimalisasi pengamalan nilai-nilai Pancasila. Oleh karenanya di perlukan nilai-nilai Pancasila sebagai cara dalam menyikapi persolan tersebut.

Globalisasi hampir melenyapkan setiap bangsa tentunya memberikan tantangan yang mau tidak mau harus bangsa ini taklukkan. Secara umum globalisasi adalah suatu perubahan sosial dalam bentuk semakin bertambahnya keterkaitan antara masyarakat dengan faktor-faktor yang terjadi akibat transkulturasi dan perkembangan teknologi modern. Era keterbukaan sudah dan mulai mengakar kuat, identitas nasional adalah barang mutlak yang harus dipegang agar tidak terbawa arus dan seragam yang melenyapkan warna lokal serta tradisional bersamanya. Identitas nasional, dalam hal ini Pancasila mempunyai tugas menjadi ciri khas, pembeda bangsa kita dengan bangsa lain selain setumpuk tugas-tugas mendasar lainnya. Pancasila bukanlah sesuatu yang beku dan statis, Pancasila cenderung terbuka, dinamis selaras dengan keinginan maju masyarakat penganutnya. Implikasinya ada pada identitas nasional kita yang terkesan terbuka, serta terus berkembang untuk diperbaharui maknanya agar relevan dan fungsional terhadap keadaan sekarang.(Budimansyah, 2010).

Pengaruh globalisasi ini harus disikapi dengan cepat supaya tidak mengancam eksistensi bangsa Indonesia, karena tantangan dari luar adalah globalisasi, sedangkan tantangan dari dalam adalah pluralism, jika tidak di sikapi secara cepat pula akan menjadi ancaman besar juga untuk bangsa Indonesia ini. Oleh karenannya perlau di antisipasi melalui pemahaman dan pengamalan nilia-nilai Pancasila dalam mengatasi hal tersebut.

\section{Metode}

Penelitian ini menggunakan metode penelitian dan pengembangan atau research and Development (R\&D). Model yang digunakan pada penelitian ini adalah model ADDIE. Dasar pertimbangan pemilihan model ini adalah karena langkah-langkah pengembangannya lebih fleksibel, tidak spesifik, untuk pengembangan desain instruktisional. Selain itu, model ADDIE relatif sederhana dan mudah dilaksanakan, serta sesuai dengan jenis produk akhir yang akan dikembangkan(Sugiyono, 2016). Model ADDIE karena dalam penelitian pengembangan ini didasarkan pada beberapa alasan yakni: (1) Model ini merupakan model prosedural, yaitu model yang bersifat deskriftif, menunjukkan langkah-langkah yang jelas dan cermat untuk menghasilkan produk. (2) tahap-tahap pengembangan dalam model ini sama dengan standar tahap penelitian pengembangan. (3) Model ADDIE telah digunakan secara luas dan terbukti dapat memberikan hasil yang baik.

\section{Hasil dan Pembahasan}

44 | Jurnal Civic Educatioan: Media Kajian Pancasila dan Kewarganegaraan 


\section{Keterpurukannya Pancasila Di Tengah Kehidupan Masyarakat}

Setelah memasuki era reformasi Negara Indonesia mulai berubah secara signifikan melalui penanaman nilai-nilai Pancasila dalam kehidupan sehari-hari. Namun seiring berjalannya waktu eksistensi Pancasila tidak luput mendapatkan ancaman disintegrasi bangsa yang mengakibatkan memudarnya nilia-nilai Pancasila, memudarnya nilia-nilai Pancasila merupakan sebagian digambarkan dengan hilangnya semanagat gotong royong dan saling menghargai. Belum lagi ada organisasi tertentu yang tidak sejalan dengan implementasi Pancasila bahkan menggantikannya dengan ideology lain.(Situru, 2019)

Pancasila bagaikan lentera kehabisan bahan bakar yang sedikit-demi sedikit meredup dan tidak dapat lagi menjadi penerang dan menjadi petunjuk arah bangsa dan negara Indonesia dalam mencapai tujuan kehidupannya. Kini, setelah semuanya uforia dengan konsep demokrasi dan hak asasi manusia dengan dibukanya gerbang reformasi keadaan bangsa Indonesia tampak tidak lagi mengindahkan nilai-nilai Pancasila dalam kehidupan bermasyarakat, berbangsa dan bernegara. Hal ini di tandai dengan munculnya berbagai tindak kekerasan dan kejahatan yang muncul dalam masyarakat, terjadinya bentrokan antar suku dan adanya pencitraan negatif yang dilakukan oleh elit-elit politik sebagai tokoh dan figur negawaran menambah panjang deretan ketidakterlaksanaan nilai-nilai luhur Pancasila dalam kehidupan keseharian Indonesia. Menurut pakar Pendiddikan Karakter dari Amerika yaitu Lickona, tanda-tanda tersebut dapat menggambarkan akan hancurnya sebuah bangsa.

Di tengah sejumlah kekhawatiran masyarakat akan semakin meningkatnya perpecahan masyarakat, langkah untuk kembali membangkitkan ideologi Pancasila tak semudah memalingkan wajah. Ideologi negara pernah menjadi sumber kekuatan yang dahsyat, yang dengannya sebuah negara dicirikan dan hegemoni kekuasaan dijalankan. Kebangkitan negara besar di awal abad ke-20 hampir identik dengan kebangkitan ideologi. Uni Soviet dengan "Marxisme, Materialisme-Historis", China dengan "Nasionalisme, Demokrasi, dan Sosialisme", Jepang dengan "Tennoo Koodoo Seishin", dan Jerman dengan "Sosialisme Nasional". Pancasila yang lahir di penghujung akhir masa keemasan ideologi dipengaruhi ideology nasionalis yang sudah dianut sejumlah negara yang merdeka sebelumnya. Lahir sebagai sebuah pergulatan pemikiran di dalam sidang Badan Penyelidik Usaha-usaha Persiapan Kemerdekaan Indonesia (BPUPKI-Dokuritsu Zyunbi Tyoosakai) yang bersidang pada akhir Mei hingga awal Juni 1945, Pancasila menemukan kristalisasi di dalam Pembukaan UndangUndang Dasar 1945 yang disahkan 18 Agustus 1945, sehari setelah pernyataan Kemerdekaan RI.

Meskipun gagasan Kebangsaan Indonesia dalam perjalanannya kemudian berubah urutan menjadi sila ke tiga dengan rumusan Persatuan Indonesia, jelas nasionalisme menjadi dasar ideologi yang terpenting ketika negara baru ini dihadapkan pada kemajemukan masyarakatnya. "Kehendak untuk bersatu", sebagaimana dikemukakan Ernest Renan, menjadi pengikat dari sebuah bangsa baru. Akan tetapi, tampaknya ada pergeseran makna kalau kita telusuri perjalanan ideology Pancasila. Semula ia sebagai ideologi kebangsaan yang mencoba mengatasi keragaman, menjadi sekadar alat yang bersifat represif untuk mencapai tujuan penguasa. Proses hegemoni politik membuat Pancasila sebagai alat penyamarataan daripada sebagai ideology yang berdiri di atas perbedaan-perbedaan. Di masa Orde Baru, Pancasila tidak saja sebagai dasar negara, sebagai falsafah hidup berbangsa, tetapi lebih jauh dipertandingkan dan digunakan untuk menekan perbedaan. Ia menjadi alat represi ideologi politik dan memberangus lawan politik di pentas publik. Skrining ideologi mulai dari partai politik, organisasi massa, hingga ke urusan pribadi menjadi fenomena yang mencolok selama kekuasaan Orde Baru, terlebih lagi setelah pada tahun 1978 Majelis Permusyawaratan Rakyat mengeluarkan ketetapan tentang Pedoman Penghayatan dan Pengamalan Pancasila (P4). Pada masa setelah itu, ideologi negara ini menjadi kata yang demikian masif memenuhi ruang gerak politik di negeri ini, bahkan sering kali terasa menggerahkan. 
Sebagaimana disebutkan dimuka pada era reformasi Pancasila dipersoalkan dan dijadikan kambing hitam dari berbagai keterpurukan yang dialami oleh bangsa ini. Pancasila yang seharusnya sebagai nilai, dasar moral etik bagi negara dan aparat pelaksana negara, dalam kenyataannya digunakn sebagai alat legitimasi politik. Puncak dari keadaan tersebut ditandai dengan hancurnya ekonomi nasional, maka timbullah berbagai gerakan masyarakat sebagai gerakan moral politik yang menuntut adanya reformasi disegala bidang politik, ekonomi dan hokum.(Muslimin, 2016).

Dengan adanya orde baru tumbang, mengakibatkan fobia terhadap Pancasila. Dasar Negara yang semula banyak dikagumi itu, untuk sementara waktu seolah dilupakan karena hampir selalu identik dengan rezim orde baru. Seolah-olah dikesampingkannya Pancasila ini, awalnya memang tidak nampak suatu dampak negatif yang berarti, namun semakin hari dampaknya makin terasa dan berdampak sangat fatal terhadap kehidupan berbangsa dan bernegara. Dalam kehidupan sosial, masyarakat kehilangan kendali atas dirinya, akibatnya terjadi konflik-konflik horisontal dan vertikal secara masif yang pada akhirnya melemahkan sendi-sendi persatuan dan kesatuan bangsa dan negara Indonesia. Bidang budaya, kesadaran masyarakat atas keluhuran budaya bangsa Indonesia mulai luntur, yang pada akhirnya terjadi disorientasi kepribadian bangsa yang diikuti dengan rusaknya moral generasi muda.

Kondisi tersebut menjadikan prihatin berbagai kalangan termasuk para cendekiawan maupun pejabat negara yang peduli akan hal tersebut. Sekitar tahun 2004 Azyumardi Azra menggagas rejuvenasi Pancasila sebagai faktor integratif dan salah satu fundamen identitas nasional. Seruan tersebut tampak signifikan karena proses amandemen UUDNRI 1945 sempat memunculkan Piagam Jakarta. Indonesia juga dilanda gerakan terorisme mengatas namakan agama. Tidak lama kemudian muncul gejala Perda Syariah disejumlah daerah. Rangkaian gejala tersebut seakan melengkapi kegelisahan publik selama reformasi yang mempertanyakan arah gerakan reformasi dan demokratisasi. Seruan Azyumardi direspon sejumlah kalangan.

\section{Menjaga Warisan Terbaik Bangsa}

Nilai Pancasila memberikan ruang regenerasi pemimpin bangsa yang lebih baik. Negara Indonesia merdeka bukan untuk sementara waktu tetapi selama-lamanya. Oleh karena itu, perjuangan bangsa Indonesia harus terus digalakkan. Perjuangan kita saat ini bukanlah mengangkat senjata melawan kaum imperialis. Namun, kita semua berjuang untuk menanamkan nilai Pancasila dalam kehidupan sehari-hari. Dengan demikian kita mampu bersaing, berkarya, berbangga, dan berkomitmen bersama bahwa kita adalah rakyat Indonesia(Mutiani, 2016).

Warisan termahal yang disorot oleh para pendiri bangsa adalah karakter, hal ini merupakan pokok terpenting bagi bangsa jika ingin membangun sebuah Negara, jika karakter bangsanya bagus, maka akan terlahir pula generasi yang berahlakul karimah cinta terhadap negaranya, dan rela berkorban terhadap Negara.

Bung Karno berkata, "Aku, ya Tuhan, telah Engkau beri kesempatan melihat penderitaanpenderitaan rakyat untuk mendatangkan negara Indonesia yang merdeka itu. Aku melihat pemimpin-pemimpin, ribuan, puluhan ribu, meringkuk di dalam penjara. Aku melihat rakyat menderita. Aku melihat orang-orang mengorbankan ia punya harta benda untuk tercapainya cita-cita ini. Aku melihat orang-orang didrel mati. Aku melihat orang naik tiang penggantungan. Bahkan aku pernah menerima surat daripada seorang Indonesia yang keesokan harinya akan naik tiang penggantungan. Dalam surat itu dia mengamanatkan kepada saya sebagai berikut: 'Bung Karno, besok aku akan meninggalkan dunia ini. Lanjutkanlah perjuangan kita ini'."

Hakekatnya fungsi Pancasila tidak berubah dan bahkan tidak boleh berubah, yakni tetap sebagaimana digagas secara cerdas oleh pendiri negara pada saat itu, yaitu sebagai dasar negara, sebagai ideologi nagara, maupun sebagai pandangan hidup bangsa. Akan tetapi Pancasila sebagai Ideologi terbuka harus mampu menyesuaikan perkembangan masyarakat yang terus

46| Jurnal Civic Educatioan: Media Kajian Pancasila dan Kewarganegaraan 
melaju dalam perubahan, ini artinya bahwa Pancasila perlu dikaji secara ilmiah dalam rangka aktualisasi. Sebagai dasar sekaligus ideologi negara, maka Pancsila bagi bangsa Indonesia sudah tidakbisa ditawar. Ditegaskan oleh M. Mahfud MD. bahwa Pancasila yang telah diumumkan di dalam Pembukaan Undang Dasar 1945 adalah modus vivendi (kesepakatan luhur) bangsa indonesia. Pancasila sangat cocok dengan realitas bangsa Indonesia dengan berbagai kepentingan yang semula mungkin saling bertentangan secara diametral.(Muslimin, 2016)

\section{Revitalisasi nilai-nilai pancasila dalam kehidupan bermasyarakat, berbangsa dan bernegara.}

Revitalisasi nilai-nilai Pancasila yang dihasilkan perubahan konstitusi meliputi substansi dan area yang diperlukan dan luas. Secara umum, revitalisasi adalah untuk mengembalikan Pancasila pada fungsinya sebagai dasar Negara dan ideologi nasional, yaitu membangun kembali semangat nasionalisme, menegaskan kedaulatan rakyat dan supremasi hukum, menghormati hak asasi manusia, menghilangkan otoritarianisme dan sebagainya ketidakadilan yang diwarisi dari masa lalu. Revitalisasi juga dimaksudkan untuk menjaga integritas nasional dan memperkuat kemampuan bangsa untuk menjawab tantangan globalisasi.(Latief et al., 2020)

Dalam Permendagri Nomor 29 Tahun 2011 ditegaskan bahwa revitalisasi dan aktualisasi nilai-nilai Pancasila ditujukan (a) Mewujudkan manusia Indonesia berwawasan Pancasila sumber daya dengan semangat nasionalisme dan patriotisme; (b) Memberikan arahan kepada pemerintah daerah untuk melaksanakan kebijakan teknis untuk pelaksanaan dan fasilitasi dalam rangka revitalisasi dan penggerakan nilai-nilai Pancasila; (c) Menanamkan nilai-nilai Pancasila pada penyelenggara dan pemerintah di tingkat daerah, politik organisasi, organisasi kemasyarakatan, dan institusi pendidikan.

Revitalisasi dalam kehidupan berbangsa dan bernegara, harus segera diprogramkan dan dilaksanakan dengan komitmen dan konsistensi; baik dengan program-program kemasyarakatan yang dengan tulus setiap warga negara merasakan bahwa Pancasila sebagai kebutuhan bukan doktrinasi semata; ataupun dengan program-program formal melalui lembaga-lembaga yang ada seperti lembaga pendidikan maupun lembaga pemerintahan agar nilai-nilai Pancasila tersebut tetap lestari dan dapat menjadi lentera dan penunjuk arah guna tercapainya tujuan bangsa Indonesia. Saat ini, semua elemen negara berharap adanya perubahan yang mendasar agar masyarakat, bangsa dan negara kita kembali kepada jati diri nya sebagai bangsa yang besar dengan ideologi yang mendasar yang menjadi gambaran budaya Indonesia serta mantapnya pemahaman (moral Knowing), ajegnya penghayatan (moral feeling) dan konsistennya pelaksanaan (moral action) nilai-nilai luhur Pancasila dalam kehidupan seharihari.

setiap bangsa senantiasa menegakkan nilai-nilai peradabannya dengan dijiwai, dilandasi dan dipandu oleh nilai-nilai religious atau non-religious. Demikian pula halnya dengan bangsa Indonesia yang majemuk dan multikultur, kehidupan dalam bermasyarakat, berbangsa dan bernegara diwarnai oleh adanya keyakinan agama dan kepercayaan yang kuat. Disisi lain aspek sosial, budaya, politik dan ekonomi juga mewarnai kehidupan ketaanegaraan suatu bangsa. Mengamati peninggalan situs sejarah seperti candi prambanan, bororbudur, masjid, gereja dan situs agama lainya ini merupakan bukti bahwa bangsa Indonesia merupakan bangsa yang religious dulunya, serta menjadikannya pedoman hidup bagi bangsa Indonesia yang berketuhanan.

Prinsip sila kedua menunjukan adanya kesadaran bangsa Indonesia tentang menjunjung tinggi nilai-nilai kemanusiaan dan keadilan dalam pluralism bangsa Indonesia. Hali ini menunjukan adanya kodrat manusia sebagai ciptaan Tuhan yang maha Esa sebagai kesatuan dan persatuan bangsa Indonesia menjadi tuntunan hidup manusia Indonesia yang mejemuk. Justru dengan kemajemukan yang dimiliki, bangsa Indonesia memiliki kekayaan budaya yang sangat heterogen. Prinsip persatuan indonesia bukan berarti menghilangkan eksistensi, ciri dan 
identitas masing-masing suku bangsa. Eksistensi, ciri dan identitas masing-masing suku bangsa tetap terpelihara dan terjaga keberadaannya.

Prinsip sila keempat merupakan wujud prilaku gotong royong yang telah dibangun oleh bangsa Indonesia sejak dulu dalam mengambil keputusan melalui musyawarah mufakat, serta hasil yang didapatkan atas dasar kesepakatan bersama.

Uruain diatas menggambarkan tantangan bagi bangsa Indonesia yang menjemuk, dan pentingnya persatuan bangsa dalam menghadapi persoalan bangsa untuk dimasa yang akan datang, oleh sebab itu prinsip-prinsip kelembagaan tersebut harus didasari oleh musyawarah dan mufakat sebagi tuntunan bagi bangsa Indonesia dalam menjalani kehidupan kehidupan berbangsa dan bernegara yang berkeadilan, serta menjadi kristalisasi keinginan dan cita-cita bangsa untuk mewujudkan masyarakat madani yang adil dan makmur.

Melalui Revitalisasi Pancasila dapat menjadikan Pancasila seabagai public discourse ini akan menunjukan adanya reassessment penilaian kembali atas pemaknaan Pancasila selama ini, untuk kemudian menghasilkan pemikiran dan pemaknaan baru. Pancasila selama ini, untuk kemudian menghasilkan pemikiran dan pemaknaan baru. Dengan demikian, menjadikan Pancasila sebagai wacana publik merupakan tahap awal krusial untuk pengembangan kembali Pancasila sebagai ideologi terbuka, yang dapat dimaknai secara terus menerus, sehingga tetap relevan dalam kehidupan bangsa dan negara Indonesia .(Budiwibowo, 2016).

\section{Reaktualisasi nilai-nilai pancasila dalam kehidupan bermasyarakat, berbangsa dan bernegara.}

Reaktualisasi nilai-nilai Pancasila merupakan cara mengamalkan dan merealiasiakan nilai-nilai yang telah dirumuskan melalui sila-sila Pancasila sebagai Ideologi Negara, flasafah, serta pandangan hidup bagi bangsa Indonesia. Apalagi Negara Indonesia saat ini berada di tengah-tengah perkembangan dunia yang serba modern, berteknologi canggih, dan era globalisasi di segala aspek kehidupan manusia yang mencakup aspek alamiah dan aspek sosial. Meliputi wilayah, kekayaan alam dan penduduk, serta aspek social social budaya, ideology, politik pertahanan kemanan dan Ipoleksosbudhankam.(Wahyudi, 2016).

Keunggulan nilai-nilai Pancasila setara dengan ideology-ideologi besar lainnya seperti, sosilaisme marxisme dan para ahli lainnya. Pancasila merupakan perpaduan antara agama dan ahlak atau prilaku serta ilmu pengtetahuan lainnya naturalism dan barat sekuler.(Lonto \& Pangalila, 2019). Dengan uraian ini menunjukan bahwa ideology Pancasila tidak kalah hebatnya dengan ideology besar lainnya, jika di realisasikan sesuai tuntunan Pancasila akan mampu merubah kehidupan Negara Indonesia yang lebih baik untuk kedepannya.

Masyarakat yang ingin maju dan tangguh harus mampu berintegrasi dengan nilai-nilai agama, sain dan teknologi. Dengan melihat perkembangan zaman ideology harus mampu menjawab tantangan-tantangan tersebut atau, dengan kata lain, budaya dan peradaban akan melakukannya berkembang menjadi unggul dan berakhlak mulia jika dilandasi nilai-nilai moral agama dan ilmu / teknologi. Fundamental dalam Pancasila harus dipahami sebagai system niali yang tidak dipisahkan, artinya fungsi fundamental dari setiap nilai-nailai tidak salaing ekslusif, saling membutuhkan satu sama lainnya meskipun masing-masing memiliki keunggulan. Namun, jika ini tidak dilakukan, kami khawatir bahwa Pemahaman parsial yang mungkin timbul akan membawa pikiran kita pada sikap ibadah atau berlebihan penolakan Pancasila (Saifuddin, 2012).

Pentingnya untuk mengimplementasikan dan mengaktualisasikan sila-sila Pancasila dengan serius, bukan hanya sekedar menjalaninya sebagai Ideologi saja, namun bagaimana pengamalannya dapat dilakukan oleh setiap warga Negara, apalagi di era perkembangan globalisai ini Pancasila mampu dijadikan filterisasi dari pengaruh westernisasi dan modernisasi yang dapat mengancam pradaban bangsa Indonesia. Hal dikarena bangsa Indonesia memiliki cirri khas tentang dasar Negara, pandanga, maka pendekatan yang tepat yaitu menggunakan Pendekatan Pancasilais. Yang dimaksud dengan Pendekatan Pancasilais adalah cara berfikir,

48 | Jurnal Civic Educatioan: Media Kajian Pancasila dan Kewarganegaraan 
bertindak dan berperilaku dalam kehidupan sehari-hari lingkungan keluarga, masyarakat, dan kenegaraan harus selalu mempertimbangkan pengamalan sila-sila Pancasila secara konsisten.

Menurut (Wahyudi, 2016) reaktualisasi nilai-nilai Pancasila dapat dilihat berbagai aspek, yaitu meliputi aspek alamiah dan aspek sosial yang dapat diuraikan sebagai berikut:

1. Bidang Posisi dan Lokasi Indonesia

Segala Kegiatan Pembangunan yang mencakup masalah penempatan, pemeliharaan dan pengembangan yang berkaitan dengan posisi dan lokasi keseluruhan wilayah Indonesia harus senantiasa mempertimbangkan sila-sila Pancasila secara konsisten.

2. Bidang Kekayaan Alam

Pembangunan yang melibatkan kekayaan alam indonesia yang mencakup perencanaan, pelaksanaan, pengawasan, dan evaluasi pembangunan tentang pengadaan, pengolahan, pendayagunaan, dan pemanfaatan, pengembangan, serta pelestarian segala sumber daya alam Indonesia harus senantiasa mempertimbangkan pengamalan sila-sila Pancasila secara konsisten.

3. Bidang Kemampuan Penduduk

Pembangunan Sumber Daya Manusia (SDM) bagi bangsa Indonesia sangat mendesak dan tidak bias titawar lagi. Dengan pembangunan SDM yang tinggi akan menjadikan bangsa Indonesia sebagai bangsa yang terhormat di mata dunia, sehingga menjadi bangsa yang disegani oleh bangsa lain. Namun demikian dalam pembangunan SDM ini tetap mempertimbangkan pengamalan sila-sila Pancasila secara konsisten.

4. Bidang Ideologi

Pembangunan dalam rangka memperkokoh dan mempertebal ideologi berbangsa dan bernegara tidak boleh menyimpang, apalagi bertentangan ideologi bangsa Indonesia yaitu Pancasila. Sejarah telah membuktikan bahwa hanya Pancasila yang dapat mempersatuan bangsa Indonesia.

5. Bidang Politik

Pendidikan dan pembangunan di bidang politik bagi bangsa Indonesia harus berlandaskan Pancasila, sehingga tidak dapat digantikan dengan landasan yang lain, termasuk paham barat dan timur. Untuk itu pendidikan dan pembangunan politik bagi bangsa Indonesia sangat penting, dan pelaksanaannya tetap mempertimbangkan pengamalan sila-sila Pancasila secara konsisten. Pancasila dalam wujud sebagai (a) penyemangat persatuan dan kesadaran nasional (nasionalisme), yang harus dihayati dan diamalkan oleh penyelenggara negara, lembaga negara, lembaga masyarakat, dan warganegara, (b) tolok ukur eksistensi kelembagaan politik, sosial, ekonomi, dan sebagainya, (c) referensi dasar bagi sistem dan proses pemerintahan, yang prinsip-prinsipnya terejawantahkan dalam tugas-tugas legislatif, eksekutif, dan yudikatif, (d) alat pemersatu/perekat bangsa dan kebangsaan Indonesia, (e) objek kajian dari berbagai sisi dan referensi-pendukung yang berlainan/beragam, (f) serta sebagai rujukan untuk kebijakan politik, pemerintahan, hukum, dan hankam.

6. Bidang Ekonomi

Pembangunan di bidang ekonomi harus selalu berakar dan bersumber pada Pancasila secara konsisten. Pembangunan di bidang ekonomi harus mewujudkan aktualisasi Pancasila dalam wujud sebagai nilai dan ruh bagi: (a) ekonomi-kerakyatan atas prinsip kebersamaan, keadilan, dan kemandirian, (b) sistem ekonomi Pancasila yang menekankan pada harmoni mekanisme harga dan sosial (sistem ekonomi campuran), bukan pada mekanisme pasar, (c) ekonomi kerakyatan (agar rakyat bebas dari kemiskinan, keterbelakangan, penjajahan/ketergantungan, rasa was-was, dan rasa diperlakukan tidak adil, (d) pemerintah yang memiliki asset produksi dalam jumlah yang signifikan terutama dalam kegiatan ekonomi yang penting bagi negara dan yang menyangkut hidup orang banyak. Di samping itu, Pancasila diaktualisasikan sebagai pendorong dan menjamin adanya tindakan nyata, yaitu (a) anak yatim dan fakir miskin dipelihara oleh negara, (b) setiap orang berhak atas pekerjaan yang layak bagi kemanusiaan, serta (c) tidak ada diskriminasi. Untuk ini perlu 
pengembangan Sistem Ekonomi Pancasila yang rumusannya adalah yang sebagaimana diatur dalam Pasal 33 UUD 1945 (sebelum dirubah), sehingga dapat menjamin dan berpihak pada pemberdayaan koperasi serta usaha menengah, kecil, dan mikro (UMKM).

7. Bidang Sosial Budaya

Pembangunan di bidang ini merumus pada aktualisasi Pancasila dalam wujud sebagai landasan idiil bagi pembangunan pendidikan, budaya, dan keagamaan di Indonesia yang menghilangkan penonjolan kesukuan, keturunan, dan ras; ideologi terbuka yang mendorong kreativitas dan inovativitas; spirit untuk pengembangan dinamika masyarakat dalam pembentukkan watak peradaban bangsa dalam rangka mencerdaskan kehidupan bangsa; serta visi dan misi pendidikan nasional bagi anak Indonesia. Problema yang dihadapi berintikan pada masalah kebudayaan, yang pemecahannya secara mendasar adalah melalui proses pendidikan secara menyeluruh. Ideologi Negara Indonesia yang mengandung nilainilai religius, memilki pengajaran moral/sikap perilaku terhadap pergaulan masyarakatnya sehingga menjadikan warga Negara yang berkarakter sesuai dengan nilai-nilai Pancasila. Implementasi aktualisasi ini sebagai upaya untuk melaksanakan prinsip-prinsip tauhid, keadilan, kebebasan, musyawarah, persamaan, toleransi, amar makruf dan nahi munkar, serta kritik yang membangun.

\section{Kesimpulan}

Berdasarkan uraian di atas, maka dapat penulis simpulkan Sebagai berikut:

1. Pancasila menjadi warisan terbaik bangsa Indonesia yang harus dirawat dan dijaga dengan baik oleh seluruh warga Negara Indonesia. Menjaga eksistensi nilai-nilai luhurnya sampai kepada regenerasi muda.

2. Program Revitalisasi, menjadi acuan program terdahulu yang dianggap mampu untuk mensosialisasikan nilai-nilai Pancasila dalam kehidupan bermasyarakat, sehingga dapat membumikan Pancasila sebagai Ideologi yang terbaik yang dimiliki oleh Negara Indonesia.

3. Reaktualisasi nilai-nilai Pancasila sebagai upaya untuk menemukan cara dalam memberikan penafsiran Pancasila secara terbuka, menghayati, memahami, pengamalan yang sangat diperlukan bagi bangsa Indonesia, serta transformasi kepemimpinan sebagai upaya untuk menjadikan pemerintahan yang bersih dan bebas KKN.

\section{Daftar Pustaka}

Badan Penelitian dan Pengembangan Pusat Kurikulum dan Perbukuan. (2011). Pedoman Pelaksanaan Pendidikan Karakter (Berdasarkan Pengalaman Di Satuan Pendidikan Rintisan. Jakarta: Kementrian Pendidikan Nasional. Alfabeta.

Belawati, T, (2007). Pengembangan Bahan Ajar.Jakarta: Universitas Terbuka.

Eva Nur Eviyana, dkk. (2020). Pancasila dan Tokoh Pahlawan Indonesia. Yogyakarta: CV. Bintang Surya Madani.

Saifuddin, L. H. (2012). Revitalisasi Nilai-Nilai Pancasila dalam Perspektif UUD 1945. Retrieved February 20, 2019, from http://lukmansaifuddin.com/index.php?optionrevitalisasi-nilai-nilai-pancasila-dalam-perspektif-uud-1945

Budimansyah, D. (2010). Tantangan globalisasi terhadap pembinaan wawasan kebangsaan dan cinta tanah air di sekolah. Jurnal Penelitian Pendidikan.

Budiwibowo, S. (2016). Revitalisasi Pancasila Dan Bela Negara Dalam Menghadapi Tantangan Global Melalui Pembelajaran Berbasis Multikultural. Citizenship Jurnal Pancasila Dan Kewarganegaraan. https://doi.org/10.25273/citizenship.v4i2.1083

Latief, A., Nadir, M., Pangalila, T., Lonto, A. L., Suyanto, T., \& Warsono, M. (2020). Revitalizing the Value of Pancasila in the Development of the Character of Indonesian Citizens. https://doi.org/10.2991/icss-18.2018.191

Lonto, A. L., \& Pangalila, T. (2019). The existence of Pancasila Values in the Disrupted Era.

50| Jurnal Civic Educatioan: Media Kajian Pancasila dan Kewarganegaraan 
https://doi.org/10.2991/icesshum-19.2019.23

Muslimin, H. (2016). Tantangan terhadap pancasila sebagai ideologi dan dasar negara pasca reformasi. Jurnal Cakrawala Hukum. https://doi.org/10.26905/idjch.v7i1.1791

Mutiani, M. (2016). Reaktualisasi Pengamalan Nilai Pancasila untuk Demokrasi Indonesia. Sosio Didaktika: Social Science Education Journal. https://doi.org/10.15408/sd.v2i2.2822

Situru, R. S. (2019). Pancasila dan Tantangan Masa Kini. Elementariyjurnal.

Sugiyono. (2016). Research Methods Quantitative, Qualitative, and R\&D. In Bandung: Alfabeta.

Wahyudi. (2016). Reaktualisasi Nilai-Nilai Pancasila Dalam Pembangunan Karakter Bangsa Indonesia. Seminar Nasional Inovasi Pendidikan 6 Agustus 2016. 